\title{
Broadening, Deepening, and Consolidating
}

\author{
Alister Cumming, Ontario Institute for Studies in Education of the University of Toronto \\ Revised Version, Submitted to Language Assessment Quarterly
}

August 12, 2003

\author{
Author contact information: \\ Alister Cumming \\ Modern Language Centre \\ Ontario Institute for Studies in Education \\ University of Toronto \\ 252 Bloor Street West \\ Toronto, Ontario \\ Canada M5S 1V6 \\ Phone: 416-923-6641, ext, 2538 \\ Fax: 416-926-4769 \\ acumming@oise.utoronto.ca
}




\begin{abstract}
I encourage the editors of and contributors to Language Assessment Quarterly to continue, and to extend, three directions that are integral to the development of the field of language assessment: (a) to broaden the scope of inquiry and contexts that inform knowledge about language assessment; (b) to deepen the theoretical premises and philosophies of language assessment; and (c) to consolidate through systematic, critical reviews the information base of prior research on language assessment. To this end, I review various, notable studies conducted over the past decade that in my view exemplify these directions, suggesting topics or approaches that publications in the journal might productively pursue.
\end{abstract}


A new journal. New perspectives. New opportunities. In this inaugural issue of Language Assessment Quarterly $(L A Q)$. I wish to express my hopes that three directions will feature in future issues of the journal:

The three directions I encourage $L A Q$ to pursue are:

1. to broaden the scope of inquiry and contexts that inform knowledge about language assessment;

2. to deepen the theoretical premises and philosophies of language assessment; and

3. to consolidate through systematic, critical reviews the information base about prior research on language assessment.

Each of these directions has, over the past decades, made language assessment a more cognizant, scholarly, and responsible field than it was 30 or more years ago, when I found (in my initial university studies) that what was written about this topic tended merely (and uncritically) to prescribe practical steps to construct a grammar test (e.g., Lado, 1964) or to mark students' essays or pronunciation errors (e.g., Rivers, 1968).

Opportunities to develop these directions certainly exist at present in the publications that consider issues of language assessment, particularly for authors who have conducted systematic empirical research and have new data to contribute (as is attested by the range of journals and other publications cited in the present article). But I expect it will be the special privilege of $L A Q$ to be able to produce articles that encompass these three directions together in one notable context. To this end, I have organized the present article to review recent publications that I believe have been especially valuable in refining and extending knowledge about language assessment, hoping that the editors of and contributors to the new journal also consider these studies as exemplary of the quality and type of articles that will feature in these pages. The publications I cite reflect my personal interests as well as my work in contexts where English is mostly the medium and subject of assessment. Though I have aimed for significant coverage internationally, I have not tried to be fully comprehensive nor definitive. 


\section{Broadening}

The scope of studies of language assessment can usefully be broadened in at least three ways. First, we need to know more about the practices and principles of assessment in ordinary contexts of teaching and learning. Second, we need to appreciate the full range of situations and populations around the world that engage in language assessment. Third, a broader range of methods of inquiry could productively be applied to studies of language assessment. Many publications have recently set the course for these directions, indicating what and how a broadened understanding of language assessment might entail.

\section{Ordinary Assessment Practices}

Understanding language assessment in ordinary educational practices is vital not only for the work of all teachers and program administrators but also for students whose language abilities are assessed and for those such as parents or employers who have a stake in the outcomes of language learning. The vast majority of books and articles published on language assessment have focused on formal tests, rather than routine assessment practices, presumably because research funding, major policy initiatives, and professional careers are associated with formal tests, not with ordinary teaching and learning. I take it that the title of the present journal signals a shift in orientation to include a broad view of assessment in which inquiry into assessment practices in language classrooms and other settings will feature prominently.

The graduate students I teach (who are usually experienced educators pursuing masters and doctoral degrees) certainly benefit from learning about formal language tests. And over the past decade, formal testing has assumed an increasingly greater role in their teaching practices and curriculum planning and reporting (such that many fundamental intersections now exist between performance on national or psychometric tests, implementing standard curricula, and helping students understand and shape their 
personal achievements). But their professional interests, and future applications of knowledge about language assessment, reside primarily in understanding better how to do and improve routine formative or achievement assessments. For example, the ordinary work of teachers requires them to monitor and report on student improvement, to link their lessons and classroom activities to system-wide standards, and to interact regularly with individual learners and other key stakeholders about these matters in an informed and responsible manner. From this viewpoint, it is surprising how few systematic analyses there are of assessment practices in language classrooms, and thus how weak the knowledge base for pedagogical recommendations in this area actually are. Some notable exceptions include, for example, Rea-Dickins' (2001) observational studies, Grierson's (1995) survey of teachers and students, and my interviews with composition instructors in different countries (Cumming, 2001a), as well as studies of certain assessment functions where controversies over pedagogical practices have sparked research interest, such as instructors' practices for responding to students' writing (e.g., Ferris, 1997; Ferris \& Roberts, 2001; Hyland \& Hyland, 2001). But one is hard pressed to be able to cite many more publications that have tried systematically to describe language assessment practices in real classrooms as experienced by teachers, students, and program administrators. Moreover, few comprehensive frameworks exist to evaluate such practices critically. Such inquiry may be most valuable when assessment is viewed in respect to the whole context of a language curriculum, as Brindley (1998), Burns \& Hood (1995), Darling-Hammond, Ancess and Falk (1995), Lynch and Davidson (1994), and TESOL (2001) have demonstrated in a range of different contexts. But surely we need more studies that simply describe educators actually doing language assessment as well as critical analyses of the principles and variables these practices entail.

\section{Various Situations of Language Assessment}

Broadening the scope of situations in which research is conducted on language assessment is also necessary. Most published studies of language assessment have focused on young adults learning English in university contexts in English-dominant 
countries such as the United States, United Kingdom, Australia, New Zealand, or Canada. There is a certain amount of published research on the assessment of some widely-taught international languages--such as Arabic, French, German, Italian, Japanese, or Spanish--but most of this inquiry is situated in North America or Europe, and most of it in foreign language courses in universities or secondary schools. As a consequence, the knowledge base about language assessment is skewed toward these contexts and their particular interests, neglecting the majority of situations in schools, colleges, or informal adult education around the world in which language assessment happens. Not only do these local situations, and their unique requirements for language assessment, remain largely undocumented and unanalyzed, but a global perspective on their varying characteristics is lacking. It still astonishes me that despite considerable efforts in the early 1990s (documented in Cumming, 1996a), demonstrations of the value of cross-cultural comparisons of language assessment (e.g., Bachman, Davidson, Ryan \& Choi, 1995), and major efforts to benchmark language achievement across certain educational jurisdictions (e.g., North, 2000; Trim, 1998), nobody has been able, since John Carroll's studies in the 1970s (e.g., Carroll, 1975), to organize an international comparative survey of second and foreign language achievement.

More than any topic, the graduate students, teachers, and program administrators I encounter express desires to know how to do language assessment with unique populations. Assessing young children's language abilities is, for example, a topic they frequently ask about, but there remains little anyone can offer other beyond a few reports of exemplary innovations (e.g., Carpenter, Fujii \& Katoaka, 1995; Johnstone, 2000), guidelines for excluding minority populations from standardized tests (e.g., Butler \& Stevens, 2001; Solano-Flores \& Trumbull, 2003), or pedagogically oriented advice (e.g., O’Malley \& Peirce, 1996). That Douglas (2000) has been able to synthesize so many examples of language tests for specific academic, vocational, or professional purposes for adults underscores the need for more comprehensive documentation and careful analyses of such innovations in other contexts and among other populations. What of the knowledge that needs to be established on such topics as the assessment of language students with learning difficulties (e.g., Cummins, 1984)? Of aboriginal populations trying to retain their ancestral languages and cultural values (e.g., McGroarty, Beck \& 
Butler, 1995)? Of teachers' language proficiency (e.g., Elder, 2001)? Of determining the language proficiency required for specific professions (e.g., Epp, Stawychny, Bonham, \& Cumming, 2002)? Or of self-assessment (e.g., Ekbatani \& Pierson, 2000)?

\section{Diverse Methods of Inquiry}

The repertoire of research methods established for the analyses of language tests now almost dictates that the properties of new assessment instruments need to be verified through analyses based on psychometrics (e.g., classical test theory, item response theory, or generalizability theory) and/or conventional statistical procedures (e.g., ANOVA, Regression analysis, Factor analysis, multi-faceted Rasch analyses, or Structural Equation Modeling) (cf. Davidson, 2000). Applications of these analytic methods are certainly to be encouraged to the extent that they provide evidence about the validity of language tests. But other, wholly different methods of inquiry also need to be adopted to achieve a broadened understanding of language assessment.

Serious consideration of the uses of language assessment requires adopting research methods that investigate people's attitudes, beliefs, cultural values, and ways of interacting. For instance, studies using verbal reports have recently revealed many aspects of the thinking processes that examinees use to take language tests (e.g., Buck, 1992; Green, 1998) or that raters use to interpret and score the results of writing tests (e.g., Cumming, Kantor \& Powers, 2002; Lumley, 2002; Milanovic, Saville \& Shuhong, 1996). Likewise, rigorous discourse analyses have identified the types of conversational interaction that characterize oral proficiency interviews (e.g., Johnson, 2001; Lazaraton, 2002; Young \& He, 1998). Such inquiry is indispensable for understanding why people perform the ways that they do in language assessments, and thus necessary for validation.

Many forms of qualitatively oriented inquiry could help to understand integral aspects of language assessment as well as to accommodate the interests and orientations of people, such as practicing educators, who regularly do language assessment. Policy analyses, for example, are fundamental to understand how language assessment figures in state policies and is acted on in education (e.g., Brindley, 1998; Cheng, 1997; 
McNamara, 1998; Slayter, 2003). Interviews, surveys and focus groups of key stakeholders in language assessment can illuminate their attitudes and beliefs, providing sources of criteria or verification for assessments (e.g., Cumming, Grant, Mulcahy-Ernt \& Powers, in press; Rosenfeld, Leung \& Oltman, 2001). But why not probe more deeply into these matters in local contexts, for instance, through detailed case studies (e.g., Johns, 1991) or through phenomenological inquiry (e.g., Van Manen, 1990), as Tong (2000) did to study the conceptualizations of error that ESL writing instructors used in judging their students' writing? Given the value of ethnography to describe cultural preferences and interactions, and the popularity of ethnographic methods in education and the social sciences generally, it is surprising how few ethnographies of language assessment practices there are (e.g., Dehyle, 1986; Losey, 1997). Likewise, I am at a loss to explain why I cannot think of a single application of narrative inquiry (e.g., Clandinin \& Connelly, 2000; Egan, 1987) to examine teachers' beliefs about language assessment (but see Bailey, 1998; Bell, 1997; Burns \& Hood, 1995). Presumably, the epistemologies informing studies of language assessment have restricted the range of research methods adopted. As noted above, the emphasis on formal language tests has promoted analytic methods involving large sample sizes, appropriate to policy evaluation or investigating explicit hypotheses; but in striving for panoramic perspectives, such research has tended to neglect the concerns for particular contexts, cases, and people that feature in qualitatively oriented inquiry and in pedagogically oriented decision making.

\section{Deepening}

Inherent in all methods of inquiry are the philosophical foundations or epistemologies that shape the questions that people pose for research. Broadening the scope of studies of language assessment in the ways suggested above may only have value if we also develop deeper theoretical foundations of what language assessment is. The most profound reconceptualization of language assessment this past decade has come in reference to Messick's (1989) multi-faceted theory of the construct validity of tests (whose applications to language testing are documented, e.g., in Bachman, 1990; 
Chapelle, 1999; Cumming, 1996b; Kunnan, 1998, 2000). This single theory unifies the many kinds of validity evidence that can demonstrate that a test functions as it claims to. At the same time, the theory extends the range of situations that need to be investigated systematically to make this case, calling for investigations of the contexts in which a test is used in addition to the properties of the test itself.

Along with such theories of test development and use, we need theoretically informed and empirically substantiated models of language proficiency, learning, and development, as well as key sources of variability associated with them, to be able to make accurate and meaningful assessments and to explain their results (Bachman \& Cohen, 1998). Although much work on language assessment since the early 1980s has usefully rallied around theoretical concepts of communicative competence, these concepts have proved to be difficult to operationalize and verify empirically in particular assessments (Bachman \& Palmer, 1996; Harley, Allen, Cummins \& Swain, 1990; Jamieson, Jones, Kirsch, Mosenthal, \& Taylor, 2000). New efforts at theory building are needed, for example, about language testing practices, assessment methods, and even the nature of language ability, social interaction, and learning. Hopefully, new ideas about these topics will feature in the present journal alongside reports of empirical data related to them. For instance, knowledge is gradually accumulating about particular aspects of second-language performance and development in specific domains. One line of development arises from the expansive scope of corpus-based studies (e.g., Biber, Conrad, Reppen, Byrd \& Helt, 2002; Hawkey, 2003; Hinkel, 2002). Another line of development concerns multiple perspectives on components of language ability; for example, for writing in second languages, models have emerged to account for such discrete components as composing processes (Sasaki, 2002), lexical knowledge and processing (Schoonen, van Gederen, de Glopper, Hulstijn, Snellings, Simis \& Stevenson, 2002), grammatical concord (Mellow \& Cumming, 1994), and textual indicators of longterm achievement (Cumming \& Riazi, 2000; Grant \& Ginther, 2000; Hinkel, 2002). Another decade of work in these directions may well produce empirical models able to guide language assessments explicitly. But theoretical conceptualizations are needed to make sense of empirical data beyond particular contexts. In the absence of such models, data, and theories, education systems around the world have been defining curriculum 
standards to prescribe expected levels of student achievement, in effect positing their own ad hoc models of language proficiency and development within their local curriculum contexts. Systematic inquiry into these initiatives is greatly needed (Cumming, 2001b; Mckay, Coppari, Cumming, Graves, Lopriore \& Short, 2001; North, 2000).

Sensing limitations in current conceptualizations of language assessment, scholars such as Peirce (1992), Valdes and Figueroa (1994), and Shohamy (2001) have urged educators to adopt a socially critical perspective, drawing on the ideas of Bourdieu (1991), Friere (1970), or Foucault (1979). A critical perspective aims to explain the dynamics of social power in the policies and practices of language assessment, for example, providing a basis to interpret ethical issues (e.g., Kunnan, 2000) or to judge the benefits of assessment policies for particular populations (e.g., Cumming, 1994). Indeed as Corson (1997) argued, all inquiry in applied linguistics could, if aligned with principles of critical realism, aim to serve emancipatory purposes.

But it seems to me that two levels of understanding have to be established prior to knowing what in language assessment might, or might not, constitute social justice or truly lead to emancipation. The first level is a theoretical framework capable of explaining relevant phenomena. Messick's (1989) unified theory of construct validity has provided such a framework for formal language testing. But if we broaden our perspectives on language assessment to encompass all manners of educational and social policies and practices in situations around the world, then we must appeal to additional theories to explain language assessment in view of these other relevant phenomena. The theories of Bourdieu, Friere, or Foucault can help to explain, respectively, the social value of linguistic capital, the potential empowerment of disadvantaged groups, and the socio-historical basis of ideas such as discipline. But the field of language assessment is still at a preliminary stage of establishing how to utilize and act on these concepts purposefully (and indeed is still grappling with the history and implications of statistical determinism, as outlined by Gould, 1996 or Hacking, 1990, and as Fred Davidson describes in his article in the present issue of $L A Q)$. Moreover, alternative, competing theories need to be examined. The possibilities here are infinite, but as examples I can cite just two philosophers whose ideas are commonly applied in educational research, those of John Dewey (e.g., 1988; Prawat, 1998) to explain assessment in view of teaching 
and curricula or of Jurgen Habermas (e.g., 1984; Ewert, 1991) to explain assessment in view of social policies.

The second level of understanding concerns defining core concepts. In some respects, this requires scholarly reflection and analysis (as in Alderson, Clapham \& Wall, 1995; Bachman, 1990; Davies, 1990) as well as collaboration to compile tools like dictionaries of key terms (e.g., Davies, Brown, Elder, Hill, Lumley \& McNamara, 1999) or to survey jurisdictions to establish common levels of professional standards (e.g., Alderson, Davidson, Douglas, Huhta, Turner \& Wylie, 1995). But in another respect, each concept integral to language assessment needs to be examined rigorously through empirical scrutiny. This approach has featured in several especially valuable studies of language assessment, which have critically examined such taken-for-granted ideas as washback (Alderson \& Hamp-Lyons, 1996; Bailey, 1996; Burrows, 2001; Wall \& Alderson, 1996), oral fluency (Fulcher, 1996), or grammaticality judgments (Birdsong, 1989). Ultimately, these levels of core concepts, theoretical frameworks, and empirical data need to be brought together to establish a working professional consensus. I think, as an analogy, of Hornberger's $(1989,2003)$ model of continua to explain individual and societal variability in reading and writing among bilinguals. Like studies of biliteracy, the field of language assessment has been entering a similar phase of elaborating explanatory models, accounting for ordinary as well as diverse phenomena, and refining the sense of core constructs. There is much to look forward to in this regards in these pages in the future, and much for active researchers and thinkers to contribute.

\section{Consolidating}

To know what or how to broaden and deepen studies of language assessment requires critical awareness of the relevant knowledge that is already established and that is worthy of further consideration. Consolidating such information will, I hope, be a further goal of articles published in $L A Q$ (including, I would like to think, the present article). Critical review articles have played an important role in defining salient issues, new directions, and topics worthy of further examination in language assessment. Some 
have highlighted notable trends from a broad, comprehensive perspective (e.g., Alderson \& Benerjee, 2001; Bachman, 2000; Kunnan, 1999), whereas others have usefully demarcated topics of specific interest, such as computer-adaptive language testing (e.g., Chalhoub-Deville \& Deville, 1999) or concerns in analyses of language assessment policies (McNamara, 1998). Another example is the set of reviews of theories and empirical research in the framework reports prepared to guide the development of a new TOEFL; these reviews consolidate current knowledge about the assessment of English proficiency in academic settings in ways that not only express the current state of informed opinion but are also sure to shape future thinking about the testing of listening, speaking, writing, and reading abilities (Bejar, Douglas, Jamieson, Nissan \& Turner, 2000; Butler, Eignor, Jones, McNamara, \& Suomi, 2000; Cumming, Kantor, Powers, Santos \& Taylor, 2000; Enright, Grabe, Koda, Mosenthal, Mulcahy-Ernt \& Schedl, 2000). At the same time, reports are emerging on the major developments taking place at many levels across the European Community, involving languages other than English, ranging from self-assessments (e.g., Dialang) to the implementation of comprehensive curriculum policies (e.g., Trim, 1998). Compiling, categorizing, and annotating bibliographies likewise help to consolidate and make accessible information published in disparate sources (e.g., Banerjee, Clapham, Clapham \& Wall, 1999).

In addition to thematically or conceptually organized review articles, along with the types of consolidation through theory building I describe above, I encourage $L A Q$ to solicit two particular types of articles. One is meta-analysis and other forms of research synthesis (Cooper \& Hedges, 1994; Wolf, 1986). The few systematic meta-analyses that have been conducted in relation to language assessment (e.g., Dochy, Segers, \& Buehl, 1999; Norris \& Ortega, 2000; Ross, 1998) contribute so importantly to consolidating current knowledge, and provide so many implications for assessment practices, that one can only hope to read and learn from more such synthetic studies along the lines of articles that regularly appear in the Review of Educational Research. The other type of article would be chronicles and analyses of the history of particular aspects of language assessment. Publications such as Barnwell (1996), Milanovic and Weir (2003), and Spolsky (1995) stand out so uniquely in their historical perspectives on this field that they 
call for others to embark seriously on historical studies of how and why language assessment has developed the way that it has.

\section{Summary}

I appreciate that, on the one hand, I have charted out a "wish list" that may be idiosyncratic in expressing my personal interests as well as challenging for the editors of and potential contributors to the journal to fulfill. But on the other hand, I presume that the directions I have outlined conform to many of the reasons that $L A Q$ is now being launched. We all want to see more studies of language assessment that broaden, deepen, and consolidate our knowledge and abilities.

\section{References}

Alderson, J.C., Clapham, C. \& Wall, D. (1995). Language test construction and evaluation. Cambridge: Cambridge University Press.

Alderson, J.C. \& Banerjee, J. (2001). Language testing and assessment (Part 1). Language Teaching, 34, 213-236.

Alderson, J.C., Davidson, F., \& Douglas, D., Huhta, A., Turner, C. \& Wylie, E. (February, 1995). Report of the task force on testing standards to the International Language Testing Association. ERIC ED 390268. http://www.surrey.ac.uk/ELI/ilta/ilta.html

Alderson, J.C. \& Hamp-Lyons, L. (1996). TOEFL preparation courses: A study of washback. TESOL Quarterly, 13, 280-297.

Bachman, L. (1990). Fundamental considerations in language testing. Oxford: Oxford University Press.

Bachman, L. (2000). Modern language testing at the turn of the century: Assuring that what we count counts. Language Testing, 17, 1, 1-42.

Bachman, L. \& Cohen, A. (Eds.) (1998). Interfaces between second language acquisition 
and language testing research. Cambridge: Cambridge University Press.

Bachman, L., Davidson, F., Ryan, K. \& Choi, I. (1995). An investigation into the comparability of the two tests of English as a foreign language: The Cambridge -TOEFL comparability study. Cambridge: Cambridge University Press.

Bachman, L. \& Palmer, A. (1996). Language testing in practice. Oxford: Oxford University Press.

Bailey, K. (1996). Working for washback: A review of the washback concept in language testing. Language Testing, 13, 257-279.

Bailey, K. (1998). Learning about language assessment: Dilemmas, decisions, and directives. Boston: Heinle \& Heinle.

Banerjee, T., Clapham, C., \& Wall, D. (1999). ILTA Language testing bibliography, 1990-1999. Lancaster University, UK: Centre for Research in Language Education.

Barnwell, D. (1996). A history of foreign language testing in the United States: From its beginning to the present. Tempe, AZ: Bilingual Press.

Bejar, I., Douglas, D., Jamieson, J., Nissan, S., \& Turner, J. (2000).TOEFL 2000 listening framework: A working paper. TOEFL Monograph Series, Report No. 19. Princeton, NJ: Educational Testing Service.

Bell, J. (1997). Literacy, culture and identity. New York: Peter Lang.

Biber, D., Conrad, S., Reppen, R., Byrd, P., Helt, M. (2002). Speaking and writing in the university: A multidimensional comparison. TESOL Quarterly, 36, 9-48.

Birdsong, D. (1989). Metalinguistic performance and interlinguistic competence. Berlin: Springer Verlag.

Bourdieu, P. (1991). Language and symbolic power. Cambridge, MA: Harvard University Press.

Brindley, G. (1998). Outcomes-based assessment and reporting in language learning programmes: A review of the issues. Language Testing, 15, 45-85.

Buck, G. (1992). Listening comprehension: Construct validity and trait characteristics. Language Learning, 42, 313-357.

Burns, A. \& Hood, S. (Eds.) (1995). Teachers' voices: Exploring course design in a changing curriculum. Sydney, Australia: National Centre for English Language 
Teaching and Research, Macquarie University.

Burrows, C. (2001). Searching for washback: The impact of assessment in the Certificate in Spoken and Written English. In G. Brindely \& C. Burrows (Eds.) Studies in immigrant English language assessment, Vol 2 (pp. 95-184). Sydney, Australia: National Centre for English Language Teaching and Research, Macquarie University.

Butler, F. \& Stevens, R. (2001). Standardized assessment of the content knowledge of English language learners K-12: Current trends and old dilemmas. Language Testing, 18, 409-427.

Butler, F., Eignor, D., Jones, S., McNamara, T., \& Suomi, B. (2000). TOEFL 2000 speaking framework: A working paper. TOEFL Monograph Series, Report No. 20. Princeton, NJ: Educational Testing Service.

Carroll, J.B. (1975). The teaching of French as a foreign language in eight countries. New York: John Wiley \& Sons.

Carpenter, K., Fujii, N. \& Katoaka, H. (1995). An oral interview procedure for assessing second language abilities in children. Language Testing, 12, 157-181.

Chalhoub-Deville, M. \& Deville, C. (1999). Computer adaptive testing in second language contexts. Annual Review of Applied Linguistics, 19, 273-299.

Chapelle, C. (1999). Validity in language assessment. Annual Review of Applied Linguistics, 19, 254-272.

Cheng, L. (1997). How does washback influence teaching? Implications for Hong Kong. Language in Education, 11, 38-54.

Clandinin, J. \& Connelly, M. (2000). Narrative inquiry: Experience and story in qualitative research. San Francisco: Jossey-Bass.

Cumming, A. (1994). Does language assessment facilitate recent immigrants' participation in Canadian society? TESL Canada Journal, 11, 117-133.

Cumming, A. (1996a). IEA's studies of language education: Their scope and contributions. Assessment in Education, 3, 201-214.

Cumming, A. (1996b). The concept of validation in language testing. In A. Cumming \& R. Berwick (Eds.), Validation in language testing (pp. 1-14). Clevedon, UK: Multilingual Matters. 
Cumming, A. (2001a). ESL/EFL writing instructors' practices for assessment: General or specific purposes. Language Testing, 18, 207-224.

Cumming, A. (2001b). The difficulty of standards, for example in second language writing. In T. Silva \& P. Matsuda (Eds.), On second language writing (pp. 209229). Mahwah, NJ: Erlbaum.

Cumming, A., Grant, L., Mulcahy-Ernt, P. \& Powers, D. (in press). A teacher -verification study of prototype speaking and writing tasks for New TOEFL. Language Testing.

Cumming, A., Kantor, R. \& Powers, D. (2002). Decision making while rating ESL/EFL writing tasks: A descriptive framework. Modern Language Journal, 86, 67-96.

Cumming, A., Kantor, R., Powers, D., Santos, T., \& Taylor, C. (2000). TOEFL 2000 writing framework: A working paper. TOEFL Monograph Series, Report No. 18. Princeton, NJ: Educational Testing Service.

Cumming, A. \& Riazi, A. (2000). Building models of adult second-language writing instruction. Learning and Instruction, 10, 55-71.

Cummins, J. (1984). Bilingualism and special education: Issues in assessment and pedagogy. Clevedon, UK: Multilingual Matters.

Cooper, H. \& Hedges, L. (Eds.) (1994). The handbook of research synthesis. New York: Russell Sage.

Corson, D. (1997). Critical realism: An emancipatory philosophy for applied linguistics? Applied Linguistics, 18, 166-188.

Darling-Hammond, L., Ancess, J., \& Falk, B. (1995). Collaborative learning and assessment at International High School. Chapter 4 of Authentic assessment in action: Studies of schools and students at work (pp. 115-167). New York: Teachers College Press.

Davidson, F. (2000). The language tester's statistical toolbox. System, 17, 4, 605-617.

Davies, A. (1990). Principles of language testing. Oxford: Blackwell.

Davies, A., Brown, A., Elder, C., Hill, K., Lumley, T., \& McNamara, T. (1999). Dictionary of language testing. Cambridge: Cambridge University Press.

Dehyle, D. (1986). Success and failure: A micro-ethnographic comparison of Navajo and Anglo students' perceptions of testing. Curriculum Inquiry, 16, 365-389. 
Dewey, J. (1988). Experience and education. In J.A. Boydston (Ed.), John Dewey: The later works, vol. 13 (pp. 1-62). Carbondale, IL: Southern Illinois University Press. (Original work published 1939).

Dochy, F., Segers, M. \& Buehl, M. (1999). The relation between assessment practices and outcomes of studies: The case of research on prior knowledge. Review of Educational Research, 69, 145-186.

Douglas, D. (2000). Assessing languages for specific purposes. New York: Cambridge University Press.

Egan, K. (1987). Teaching as story-telling. London: Methuen.

Ekbatani, G., \& Pierson, H. (Eds.). (2000). Learner-directed assessment in ESL. Mahwah, NJ: Erlbaum.

Enright, M., Grabe, B., Koda, K., Mosenthal, P., Mulcahy-Ernt, P., \& Schedl, M. (2000). TOEFL 2000 reading framework: A working paper. TOEFL Monograph Series, Report No. 17. Princeton, NJ: Educational Testing Service.

Epp, L, Stawychny, M., Bonham, A. \& Cumming, A. (2002). Benchmarking the English language demands of the nursing profession across Canada. Winnipeg: Red River Community College. Report submitted to the Centre for Canadian Language

Benchmarks. Available at http://www.language.ca

Ewert, G. (1991). Habermas and education: A comprehensive overview of the influence of Habermas in educational literature. Review of Educational Research, 61, 345 -378 .

Ferris, D. (1997). The influence of teacher commentary on student revision. TESOL Quarterly, 31, 315-339.

Ferris, D. \& Roberts, B. (2001). Error feedback in L2 writing classes: How explicit does it need to be? Journal of Second Language Writing, 10, 161-184.

Foucault, M. (1979). Discipline and punish (A. Sheridan, Trans.). New York: Vintage.

Freire, P. (1970). Pedagogy of the oppressed. (M. Ramos, Trans.). New York: Seabury.

Gould, S.J. (1996). The mismeasure of man. New York: Norton.

Grant, L. \& Ginther, L. (2000). Using computer-tagged linguistic features to describe L2 writing differences. Journal of Second Language Writing, 9, 123-145.

Grierson, J. (1995). Classroom-based assessment in Intensive English Centres. In G. 
Brindley (Ed.), Language assessment in action (pp. 195-236). Macquarie University: National Centre for English Language Teaching and Research, Australia.

Green, A. (1998). Verbal protocol analysis in language testing research: A handbook. Cambridge: Cambridge University Press.

Habermas, J. (1984). The theory of communicative action, Vol. 1: Reason and rationalization of society. Boston: Beacon.

Hacking, I. (1990). The taming of chance. New York: Cambridge University Press.

Harley, B., Allen, P., Cummins, J. \& Swain, M. (Eds.) The development of second language proficiency. Cambridge: Cambridge University Press.

Hawkey, R. (2003). The development of CELS: A modular approach to testing English language skills. Cambridge: Cambridge University Press.

Hinkel, E. (2002). Second language writers' text: Linguistic and rhetorical features. Mahwah, NJ: Erlbaum.

Hornberger, N. (1989). Continua of biliteracy. Review of Educational Research, 59, 271 $-296$.

Hornberger, N. (Ed.) (2003). Continua of biliteracy: An ecological framework for educational policy, research, and practice in multilingual settings. Clevedon, UK: Multilingual Matters.

Hyland, F. \& Hyland, K. (2001). Sugaring the pill: Praise and criticism in written feedback. Journal of Second Language Writing, 10, 185-184.

Jamieson, J., Jones, S., Kirsch, I., Mosenthal, P., \& Taylor, C. (2000). TOEFL 2000 framework: A working paper. TOEFL Monograph Series Report No. 16. Princeton, NJ: Educational Testing Service.

Johns, A. (1991). Interpreting an English competency exam: The frustrations of an ESL science student. Written Communication, 8, 379-401.

Johnson, M. (2001). The art of non-conversation: A re-examination of the validity of the oral proficiency interview. New Haven, CT: Yale University Press.

Johnstone, R. (2000). Context-sensitive assessment of modern languages in primary (elementary) and early secondary education: Scotland and the European experience. Language Testing, 17, 123-143. 
Kunnan, A. (Ed.) (1998). Validation in language assessment. Mahwah, NJ: Erlbaum.

Kunnan, A. (1999). Recent developments in language testing. Annual Review of Applied Linguistics, 19, 235-253.

Kunnan, A. (Ed.) (2000). Fairness and validation in language assessment. Cambridge: Cambridge University Press.

Lado, R. (1964). Language testing: The construction and use of foreign language tests. New York: McGraw-Hill.

Lazaraton, A. (2002). A qualitative approach to the validation of oral language tests. Cambridge: Cambridge University Press.

Losey, K. (1997). Listen to the silences: Mexican American interaction in the composition classroom and the community. Norwood, NJ: Ablex.

Lumley, T. (2002). Assessment criteria in a large-scale writing test: What do they really mean to the raters? Language Testing, 19, 246-276.

Lynch, B. \& Davidson, F. (1994). Criterion-reference test development: Linking curricula, teachers, and tests. TESOL Quarterly, 28, 727-743.

McGroarty, M., Beck, A., \& Butler, F. (1995). Policy issues in assessing indigenous languages: A Navajo case. Applied Linguistics, 16, 323-343.

McKay, P., Coppari, P., Cumming, A., Graves, K., Lopriore, L. \& Short, D. (2001). Language standards: An international perspective, parts 1 and 2. TESOL Matters, $11,2,1-14 ; 3,11,5$

McNamara, T. (1998). Policy and social considerations in language assessment. Annual Review of Applied Linguistics, 18, 304-319.

Mellow, J.D. \& Cumming, A. (1994). Concord in interlanguage: Efficiency or priming? Applied Linguistics, 15, 442-473.

Messick, S. (1989). Validity. In R. Linn (Ed.), Educational measurement (pp. 13-103). New York: Macmillan.

Milanovic, M., Saville, H. \& Shuhong, S. (1996). A study of the decision-making behavior of composition markers. In M. Milanovic \& N. Saville (Eds.), Studies in language testing 3: Performance testing, cognition and assessment (pp. 92-111). Cambridge: Cambridge University Press.

Norris, J. \& Ortega, L. (2000). Effectiveness of L2 instruction: A research synthesis and 
quantitative meta-analysis. Language Learning, 50, 417-528.

North, B. (2000). The development of a common framework scale of language proficiency. New York, Peter Lang.

O’Malley, J.M. \& Peirce, L. (1996). Authentic assessment for English language learners: Practical approaches for teachers. Reading, MA: Addison-Wesley.

Peirce, B. (1992). Demystifying the TOEFL reading test. TESOL Quarterly, 26, 665-689.

Prawat, R. (1998). Current self-regulation views of learning and motivation viewed through a Deweyan lens. American Educational Research Journal, 35, 199-224.

Rea-Dickins, P. (2001). Mirror, mirror on the wall: Identifying processes of classroom assessment. Language Testing, 18, 4, 429-462.

Rosenfeld, M., Leung, S. \& Oltman, P. (2001). The reading, writing, speaking, and listening tasks important for academic success at the undergraduate and graduate levels. TOEFL Monograph Series 21. Princeton, NJ: Educational Testing Service.

Ross, S. (1998). Self-assessment in second language testing: A meta-analysis and analysis of experiential factors. Language Testing, 15, 1-20.

Rivers, W. (1968). Teaching foreign-language skills. Chicago: University of Chicago Press.

Sasaki, M. (2002). Building an empirically-based model of EFL learners' writing processes. In G. Rijlaarsdam (Series Ed.) \& S. Ransdell \& M. Barbier (Volume Eds.), Studies in writing, volume 11: New directions in research in L2 writing (pp. 49-80). Dordrecht, The Netherlands:Kluwer.

Schoonen, R., van Gelderen, A., de Glopper, K., Hulstijn, J., Snellings, P., Simis, A., \& Stevenson, M. (2002). Linguistic knowledge, metacognitive knowledge and retrieval speed in L1, L2 and EFL writing. In G. Rijlaarsdam (Series Ed.) \& S. Ransdell \& M. Barbier (Volume Eds.), Studies in writing, volume 11: New directions in research in L2 writing (pp. 101-122). Dordrecht, The Netherlands: Kluwer.

Shohamy, E. (2001). The power of tests: A critical perspective on the uses of language tests. New York: Pearson.

Slayter, H. (2003). Responding to change in English language assessment. Prospect, 18, 
42-52.

Solano-Flores, G. \& Trumbull, E. (2003). Examining language in context: The need for new research and practice paradigms in the testing of English-language learners. Educational Researcher, 32, 2, 3-13.

Spolsky, B. (1995). Measured words: The development of objective language testing. Oxford: Oxford University Press.

TESOL (Teachers of English to Speakers of Other Languages). (2001). Scenarios for ESL standards-based assessment. Alexandria, VA: Authors.

Tong, A. K.K. (2000). You're never really gonna be eliminating them: A phenomenological study of ESL instructors' perceptions of written errors among adult ESL learners. Unpublished Ph.D. thesis, Department of Curriculum, Teaching and Learning, University of Toronto.

Trim, J. (1998). European perspectives on modern language learning: Contributions to the Modern Languages Project of the Council of Europe. Language Teaching, 31, 206-217.

Valdes, G. \& Figueroa, R. (1994). Bilingualism and testing: A special case of bias. Norwood, NJ: Ablex.

Wall, D. \& Alderson, J.C. (1996). Examining washback: The Sri Lankan impact study. In

A. Cumming \& R. Berwick (Eds.), Validation in language testing (pp. 194-221). Clevedon, UK: Multingual Matters.

Weir, C. \& Milanovic, M. (2003). Continuity and innovation: Revising the Cambridge Proficiency in English examination: 1913-2002. Cambridge: Cambridge University Press.

Wolf, F. (1986). Meta-analysis: Quantitative methods for research synthesis. Beverly Hills, CA: Sage.

Van Manen, M. (1990). Researching lived experience: Human science for an action sensitive pedagogy. London, ON: Althouse Press.

Young, R. \& He, A. (Eds.) (1998). Talking and testing: Discourse approaches to the assessment of oral proficiency. Amsterdam: John Benjamins. 